\title{
Antara Ideal dan Praktik: Transformasi Spiritual Anggota Perempuan Berdasarkan Nilai-Nilai Keperempuanan Wahdah Islamiyah
}

\author{
Syarifah Raodatul Aswah
}

Departemen Antropologi, Fakultas Ilmu Sosial dan Ilmu Politik Universitas Hasanuddin E-mail: syarifahraodatulaswahhhh@@gmail.com

\begin{tabular}{l}
\hline ARTICLE INFO \\
\hline Keywords: \\
Womanhood; Wahdah \\
Islamiyah; new \\
members; murabbiah; \\
hijab; mother/wife; \\
Lembaga Muslimah. \\
How to cite: \\
Aswah, Syarifah Raodatul. \\
(2017). Antara Ideal dan \\
Praktik: Transformasi \\
Spiritual, Anggota \\
Perempuan Berdasarkan \\
Nilai-Nilai \\
Keperempuanan Wahdah \\
Islamiyah. Etnosia: Jurnal \\
Etnografi Indonesia 2(2): \\
177-200.
\end{tabular}

\begin{abstract}
Wahdah Islamiyah (WI) is a community organization (ormas) based in Makassar under the aupices of Yayasan Pesantren Wahdah Islamiyah (YPWI). Members of WI are the followers of Salafi, a social movement which tries to practice Islamic values according to the understanding of As-Salaf As-Shalih. While members of WI consists of men and women, this article is focused on how female members of WI practice the ideal values of womenhood set by WI in the everyday life. The research findings indicates that members of WI consist of three categories, namely: new members, teachers (murabbiah), and administrative staff of its Lembaga Muslimah WI. The value of womenhood is set by the organization, and is classified into three, namely how to dress properly, how women behaves towards the opposite sex, and how 'to become a wife/mother'. The application of such values is not always syncronised with the ideal ones, depending on their level of membership and which value and which condition faced by the members. While new members tend to have a space for negotiation; murabbiah is more advance than new members in the practice of womenhood values, which can be seen from how they dress (ber-hijab) and how they interact with the opposite sex; staff of Lembaga Muslimah WI is focused on how to practice such values in relation to how 'to become a wife/mother'. Thus, women transform themselves spiritually on the basis of womenhood values as they become part of the organization and the level of their membership.
\end{abstract}

Copyright (C) 2017 ETNOSIA. All rights reserved.

\section{Pendahuluan}

Perempuan dalam Islam selalu menjadi topik yang sangat menarik untuk dibicarakan. Jika ada isu yang menjadi alarm di benak seorang Muslim maupun non-Muslim itu adalah isu mengenai status perempuan dalam Islam. Media Barat secara konsisten menyerang posisi wanita Muslim, yang kemudian 
dibalas dengan emosi oleh umat Islam (Siddiqui 2010). Media Barat melihat bagaimana Islam memperlakukan perempuan ataupun status perempuan dalam Islam sebagai sebuah penindasan terhadap perempuan. Hal inilah yang memicu konflik karena bagi umat Islam cara tersebut adalah sebuah tanda bahwa Islam memuliakan perempuan (Stacey 2013). Ini menunjukkan cara pandang tentang bagaimana perlakukan terhadap perempuan dalam Islam yang menimbulkan perdebatan. Padahal sejumlah literatur menunjukkan bagaimana Islam memromosikan kesetaraan gender (misalnya, Mernissi 1993, Wadud 1994, Engineer 1992, Umar 1999).

Menurut nilai yang dianut oleh WI, Islam tidak membolehkan perempuan untuk menggunakan kecantikan tubuh dan wajahnya untuk mendatangkan keuntungan materi. Kontes Miss World dan sejenisnya tidak akan pernah ada selamanya pada masyarakat Islam. Tubuh wanita tidak untuk dieksploitasi dan diperdagangkan, melainkan harus ditutup dengan busana Muslimah yang memuliakan dirinya. 'Wanita wajib menutup aurat, selain wajah dan dua telapak tangan'. Kutipan ini merupakan respon dari salah satu organisasi Islam Hizbut Tahrir Indonesia terhadap pandangan bahwa Islam menindas perempuan. ${ }^{1}$ Respon lain datang dari organisasi Islam Wahdah Islamiyah (selanjutnya disingkat WI) yang berpendapat bahwa pada dasarnya mereka yang non-Islam menginginkan kaum Muslimah untuk menjadi 'perempuan modern', yang berprilaku seperti perempuan yang kehilangan harga diri, yang dapat dinikmati dan dimiliki oleh siapapun yang menginginkannya. Padahal, justru itu yang merupakan hakikat 'perempuan jahiliyyah'. ${ }^{2}$

Dalam artikelnya The Social Construction of 'Self' and Womanhood in a Hindu Village of Bangladesh, Jahan (2015) menunjukkan bahwa perempuan mengonstruksikan citra diri mereka yang berhubungan dengan nilai keperempuanan dan bagaimana mereka dibedakan dalam kaitan dengan basis sosial mereka. Dalam konteks WI, bagaimana organisasi mengidealkan tentang nilai-nilai keperempuanan dan bagaimana persepsi perempuan WI melihat diri mereka dalam kaitan dengan nilai-nilai yang dianut dalam organisasi tempat mereka bernaung dan bagaimana mereka membedakan diri mereka dengan perempuan lain di luar WI.

Kajian-kajian tentang perempuan Muslim di Indonesia kebanyakan berfokus pada bagaimana perempuan Muslim moderat dan liberal serta feminis Muslim

1 (https://hizbut-tahrir.or.id/2013/08/30/barat-justru-merendahkan-wanita/).

2 (http:// wahdahmakassar.org/gerakan-penentang-hijab-dan-kiat-membendungnya/) 
mengkritisi interpretasi teks-teks Islam yang patriarkal yang ditegakkan oleh kelompok-kelompok ultra-konservatif (baca, misalnya, Robinson 2006, 2008, 2009; Rinaldo 2008; Blackburn 2008, Wieringa 2009; Qibtiyah 2012). Sementara gerakan-gerakan konservatif dan ultra-konservatif dianggap 'tidak bersahabat' terhadap perempuan dan sering dianggap memosisikan perempuan sebagai warga kelas dua (Zine 2002:12; Rizaldo 2008:1784). Nisa (2012) justru melihat eksistensi perempuan anggota WI melalui Lembaga Muslimah berusaha untuk memosisikan perempuan sebagai agen penting dalam pembangunan, yang mendemonstrasikan bagaimana ketidaknampakan mereka (invisibility) di ranah publik oleh orang luar (outsiders) menjadi nampak (visible) karena peran tersebut, meskipun ini terjadi di ranah yang bergender. Nisa dalam artikel ini mengeksplorasi bagaimana komitmen perempuan tertanam pada performa 'keshalehan publik' (public piety). ${ }^{3}$ Artikel ini terfokus pada bagaimana perempuan (ketika menjadi bagian dari WI) mentransformasikan diri mereka secara spiritual dengan merujuk pada nilai-nilai keperempuan yang diatur dalam WI. Transformasi spiritual adalah sebuah konsep yang dikembangkan oleh Deller (2014) yang mengadopsi praktik-praktik agama atau spiritual sebagai bagian dari perjalanan transformasi diri. Transformasi diri anggota perempuan WI terjadi secara bertahap berdasarkan level keanggotaan mereka.

\section{Metode Penelitian}

Penelitian ini dilakukan di Kota Makassar karena WI berbasis di kota ini dan juga merupakan tempat dimana organisasi ini lahir, tumbuh dan berkembang. Organisasi WI dipilih karena merupakan salah satu organisasi Islam yang bisa dikatakan radikal karena ketat bersandar pada Al-Qur'an dan As-Sunnah dengan pemahaman As-Salaf As-Sālih (Sugiyarto 2013:86).

Dengan menggunakan pendekatan kualitatif, saya menggabungkan antara wawancara, observasi dan konten analisis sebagai teknik-teknik pengumpulan data yang digunakan dalam penelitian ini. Wawancara dilakukan untuk melihat bagaimana keseharian anggota WI dalam penerapannya terhadap nilainilai ideal perempuan dalam organisasi WI. Wawancara dilakukan terhadap 16 anggota WI yang terdiri atas 3 pengurus Lembaga Muslimah WI, 7 murabbiah, dan 3 anggota baru yang semuanya perempuan.

\footnotetext{
3 'Public piety' adalah konsep yang dikembangkan oleh Deeb (2006) yang merujuk pada ekspresi komitmenr keagamaan yang bergantung pada visibilitas.
} 


\begin{tabular}{ccccc}
\hline No. & Nama & $\begin{array}{c}\text { Usia } \\
\text { (Tahun) }\end{array}$ & $\begin{array}{c}\text { Status } \\
\text { Permikahan }\end{array}$ & Status Keanggotaan \\
\hline 1. & Sakinah & 40 tahun & Menikah & Pengurus Lembaga Muslimah WI \\
\hline 2. & Hilda & 40 tahun & Menikah & Pengurus Lembaga Muslimah WI \\
\hline 6. & Melati & 41 tahun & Menikah & Pengurus Lembaga Muslimah WI \\
\hline 3. & Hani & 28 tahun & Belum Menikah & Pengurus Lembaga Muslimah WI \\
\hline 4. & Viska & 27 tahun & Belum Menikah & Pengurus Lembaga Muslimah WI \\
\hline 5. & Nurul & 28 tahun & Belum Menikah & Pengurus Lembaga Muslimah WI \\
\hline 7. & Sida & 21 tahun & Belum Menikah & Murabbiah \\
\hline 8. & Siska & 24 tahun & Belum Menikah & Murabbiah \\
\hline 9. & Rina & 24 tahun & Belum Menikah & Murabbiah \\
\hline 10. & Nisa & 23 tahun & Belum Menikah & Murabbiah \\
\hline 11. & Sinta & 23 tahun & Belum Menikah & Murabbiah \\
\hline 12. & Dwi & 23 tahun & Belum Menikah & Murabbiah \\
\hline 13. & Rosna & 25 tahun & Belum Menikah & Murabbiah \\
\hline 14 & Ifah & 19 tahun & Belum Menikah & Anggota Baru \\
\hline 15 & Mawar & 20 tahun & Belum Menikah & Anggota Baru \\
\hline 16 & Rana & 18 tahun & Belum Menikah & Anggota Baru \\
\hline & & & &
\end{tabular}

Observasi dilakukan dengan menghadiri pertemuan-pertemuan atau kegiatankegiatan yang di lakukan oleh anggota WI, seperti tarbiyah (kelompok diskusi kecil mengenai Islam), makan bersama, dan OASIS (obrolan Adem Seputar Islam). OASIS sebenarnya merupakan kegiatan yang dibuat oleh Lembaga Dakwah Kampus Mahasiswa Muslim Sospol Universitas Hasanuddin (LDKMMS-UNHAS), tetapi melihat banyaknya anggota dari LDK-MMS yang juga merupakan anggota WI, sehingga saya memutuskan untuk ikut dalam kegiatan ini. Observasi dilakukan untuk melihat bagaimana anggota perempuan WI berinteraksi dengan anggota maupun yang bukan anggota WI, dan bagaimana pemahaman ideal dari organisasi disebarkan luaskankepada setiap anggota maupun yang bukan anggota.

Konten analisis dilakukan untuk melihat bagaimana nilai-nilai keperempuanan yang ideal dalam organisasi WI, konten-konten yang dianalisis berupa buku, selembaran yang berupa buletin mingguan, artikel, dan juga fatwa yang dikeluarkan oleh WI.

Informan terlebih dahulu dimintai kesediaannya untuk diwawancarai dan direkam. Sebanyak tiga informan tidak ingin direkam karena menganggap akan menciptakan suasana yang terlalu formal, sementara yang lainnya tidak mempersoalkannya. Seluruh nama yang disebutkan dalam tulisan ini disamarkan (pseudonym) hal ini dilakukan atas permintaan dari informan itu sendiri. 


\section{Pembahasan}

\subsection{Wahdah Islamiyah: Apa dan Bagaimana? ${ }^{4}$}

Organisasi yang pertama kali didirikan pada tanggal 18 Juni 1988 inibernama Yayasan Fathul Muin (YFM). Demi menghindari kesan mengkultuskan ketokohan K.H. Fathul Muin Dg. Maggading, seorang ulama Sulsel yang di masa hidupnya menjadi pembina para pendiri YFM. Agar lembaga ini dapat menjadi wadah 'persatuan ummat', maka pada tanggal 19 Februari 1998, nama YFM berubah secara resmi menjadi Yayasan Wahdah Islamiyah (YWI). WI berkembang dan membentuk cabang yang tersebar di Indonesia. Sehubungan dengan adanya rencana untuk mendirikan perguruan tinggi Islam, maka YWI menambah sebuah kata dalam identitasnya menjadi Yayasan Pesantren Wahdah Islamiyah (YPWI). Ini bertujuan untuk menaungi lembaga-lembaga pendidikan tingginya.

Dengan perkembangan Dakwah WI yang sangat pesat, lembaga ini dianggap tidak memungkinkan lagi bergerak dalam bentuk yayasan, maka dalam Musyawarah YPWI ke-2, tanggal 1 Shafar 1422 H (14 April 2002) disepakati untuk mendirikan organisasi massa (ormas) dengan nama yangsama, yaitu Wahdah Islamiyah. Sejak saat itulah, YPWI yang merupakan cikal bakal berdirinya ormas WI disederhanakan fungsinya sebagai lembaga yang mengelola pendidikan formal milik WI.

Sebagai sebuah organisasi massa, Wahdah Islamiyah-Bahasa Arab yang berarti 'Persatuan Islam' - adalah sebuah organisasi Islam di Indonesia yang bertujuan utama untuk mempersatukan Islam dalam bingkai aqidah Ahlu Sunnah Wal-Jama'ah. Organisasi massa WI bergerak di berbagai bidang, yakni pendidikan, da'wah dan kaderisasi, kesehatan dan lingkungan hidup, pengembangan usaha, sosial, zakat, infak dan shadaqah (ZIS), informasi dan komunikasi, waqaf, perencanaan dan pembangunan (WP2), litbang dan pengembangan SDM (PSDM), pernikahan dan pembinaan keluarga sakinah (P2KS), dan bidang yang terkait dengan Muslimah.

Adapun misi dari WI, sebagaimana dijelaskan dalam Profil Wahdah Islamiyah, adalah untuk menegakkan syiar Islam dan menyebarkan pemahaman Islam

\footnotetext{
4 Informasi tentang Sejarah Wahdah Islamiyah kebanyakan dikutip dari Wikipedia (https://id.wikipedia.org/wiki/Wahdah_Islamiyah)
} 
yang benar, membangun persatuan umat dan ukhuwah Islamiyah yang dilandasi semangat ta'awun (kerjasama) dan tanashuh (saling menasehati), mewujudkan institusi/lembaga pendidikan dan ekonomi yang Islami dan berkualitas, dan membentuk generasi Islam yang Rabbani dan menjadi pelopor dalam berbagai bidang kehidupan. ${ }^{5}$

Salah satu bentuk da'wah yang dilakukan oleh WI adalah da'wah di dalam kampus dengan berasosiasi dengan Unit Kegiatan Mahasiswa Lembaga Dakwah Kampus Universitas Hasanuddin (LDK), baik yang ada di tingkat fakultas, maupun tingkat universitas untuk menyebarkan pemahamantentang Islam. Dalam suatu tarbiyah yang diikuti oleh anggota WI, yang diadakan oleh LDK Mahasiswa Muslim Sospol (MMS), salah satu materi tarbiyah yang diberikan adalah pemahaman mengenai tiga generasi pertama Islam, yaitu Nabi dan sahabatnya, tābi'een (pengikut dari nabi dan sahabatnya) dan tābi'u altābi'een (pengikut dari tābi'een) yang merupakan pemahaman Al-Salaf Al-Sälihyang mendasarkan pemahaman dan amaliyahnya pada Al-Qur'an dan AsSunnah. Selain itu, buku yang digunakan dalam memberikan materi tarbiyah adalah buku yang diterbitkan dan diperuntukkan secara internal bagi anggota WI yang tidak diperjual belikan. Selain itu, ada buletin-Al-Balagh-yang diterbitkan setiap minggu (lihat Gambar 1).

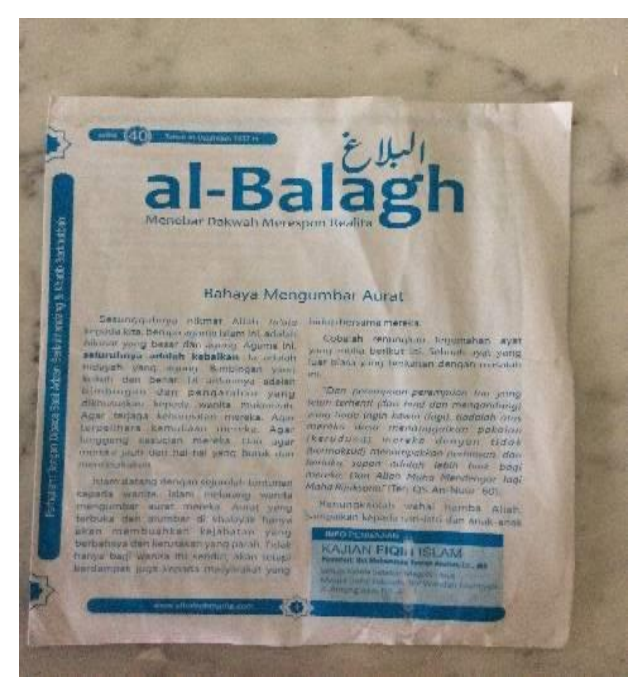

Gambar 1. Buletin WI, Al-Balagh

Anggota WI berbeda berdasarkan status keaggotaannya, penguasaan ilmunya, dan status perkawinannya, yang dalam konteks ini diklasifikasikan ke dalam 3 kategori, yaitu: anggota baru, guru (murabbiah), dan pengurus Lembaga Muslimah, yang secara resmi dibentuk oleh WI tahun 2005 dan bertujuan untuk

${ }^{5}$ (http://www.wahdahtamalate.com/p/sejarah-singkat-berdirinya-wahdah.html) 
membantu cabang-cabang dan afiliasinya dengan memberikan supervisi, konsultasi dan koordinasi, serta memiliki otoritas untuk mengaktifkan komite cabang Lembaga Muslimah.

Kategori anggota baru merupakan anggota yang baru bergabung dengan tarbiyah yang dilaksanakan oleh WI tentang nilai-nilai ideal keperempuanan (baca sessi berikutnya) yang pada praktiknya belum sesuai dengan nilai-nilai tersebut. Murabbiah merupakan guru yang mengajarkan anggota baru tentang Islam dalam 1 kelompok tarbiyah, sehingga dalam organisasi WI terdapat beberapa murabbiah dan kelompok tarbiyah. Dari murabbiah inilah seorang anggota baru belajar mengenai Islam dan bagaimana berprilaku sebagai anggota WI. Berdasarkan keanggotaannya, maka kedudukan murabbiah setingkat lebih tinggi dibandingkan dengan anggota baru. Sedang untuk kategori pengurus Lembaga Muslimah WI, hampir semuanya termasuk dalam kategori istri dan ibu. Status ini sebagai indikasi bahwa anggota tersebut tidak saja memahami nilai-nilai keperempuanan ideal sebagai anggota WI, tapi mereka juga telah memraktekkanya, dan kedudukannya setingkat lebih tinggi dari murabbiah. Sementara bagi pengurus Lembaga Muslimah WI yang belum menikah kesemuanya berada pada umur yang merupakan usia dimana seorang wanita harusnya telah menikah yaitu sekitar 25-28 tahun dalam hal penerapan nilai ideal dari organisasi WI itu sendiri pengurus Lembaga Muslimah Wahdah Islamiyah juga setingkat lebih tinggi dari murabbiah karena mereka lebih mengerti mengenai nilai ideal yang ada pada organisasi WI dan memraktekkan secara hal ini berhubungan dengan status mereka sebagai pengurus Lembaga Muslimah WI.

\subsection{Nilai-Nilai Keperempuanan yang Diidealkan}

Bagaimana nilai-nilai keperempuan yang diatur dalam WI? Dalam konteks ini, pembahasan mengenai nilai-nilai keperempuanan yang ideal dalam organisasi WI akan dijelaskan berdasarkan 3 aspek, yakni: hijab, prilaku perempuan terhadap laki-laki, dan bagaimana perempuan berperan sebagai seorang ibu.

\subsubsection{Hijab}

Hijab, sebagaimana yang dijelaskan dalam artikel Hijab Wanita Muslimah yang di-posting pada website resmi WI, berasal dari bahasa Arab yang berarti 'tirai'. Secara lebih luas, hijab juga bermakna setiap yang menutupi hal-hal yang dituntut untuk ditutupi atau menghalangi hal-hal yang terlarang untuk digapai. Selain itu, hijab juga mencakup segala sesuatu yang dapat menjadi 
'penghalang' dari tujuan yang diinginkan, seperti tirai, penjaga pintu, badan, kelemahan, dan maksiat. Selain makna epistemologinya, hijab juga bermakna sebagai 'pakaian bagi penggunanya', atau dalam konteks yang lebih sempit hijab adalah penutup kepala umum disebut dengan istilah jilbab.

Dalam organisasi WI, setiap Muslimah wajib untuk mengenakan hijab. Hal ini didasarkan pada sebuah ayat dalam Al-Qur'an, sebagai berikut:

Wahai Nabi! Katakanlah kepada istri-istrimu, anak-anak perempuanmu dan istri-istri orang beriman, 'Hendaklah mereka menutupkan jilbabnya keseluruh tubuh mereka, yang demikian itu agar mereka lebih mudah untuk dikenali, sehingga mereka tidak diganggu. Dan Allah Maha Pengampun, Maha Penyayang' (Q.S. Al-Ahzab:59).

Penggunaan hijab didasarkan pada dua tujuan. Pertama, untuk menghindarkan diri perempuan sebagai 'penggoda syahwat laki-laki'. Perempuan merupakan fitnah paling besar bagi laki-laki. Hal ini di dasarkan pada sabda Rasulullah Muhammad S.A.W.: 'Tidak pernah kutinggalkan setelahku fitnah yang lebih dahsyat bagi kaum pria daripada fitnah wanita (HR. Bukhari dan Muslim). Kedua, untuk menghindarkan diri dari gangguan lawan jenis yang dapat membahayakan diri perempuan, seperti pelecehan seksual, pemerkosaan, dll.Dalam konteks ini, baik laki-laki maupun perempuan dianggap sebagai orang-orang yang berpotensi untuk membahayakan satu sama lain. Oleh karenanya, laki-laki Muslim di wajibkan untuk 'menundukkan pandangannya', sementara perempuan diwajibkan untuk 'berhijab'. Ini menunjukkan bahwa tindakan preventif untuk menghindari fitnah yang berbeda berdasarkan gender.

Atas dasar pemahaman bahwa hijab merupakan sesuatu yang urgen, WI menetapkan syarat dan ketentuan hijab berdasarkan Syariat Islam yang di sebarkan melalui website mereka, yang meliputi: seluruh tubuh (termasuk wajah dan telapak tangan) yang didasarkan pada menurut pendapat ulama, dimana pendapat ulama ini didasarkan pada Q.S. An-Nur (ayat 31) dan AlAhzab (ayat 59). Ada pula ulama yang membolehkan membuka wajah serta kedua telapak tangan tersebut diperbolehkan dengan 2 syarat, yaitu: (1) wajah dan kedua telapak tangan tersebut terlepas dari segala bentuk perhiasan serta aman dari fitnah, (2) bukanberupa perhiasan yang berbentuk pakaian (busana dengan motif tertentu, seperti batik, bunga, dll.), pakaian dengan motif yang berwujud mahluk hidup (seperti manusia, hewan dll.), (3) longgar dan tidak sempit atau ketat, (4) kainnya tebal dan tidak tembus pandang, (5) tidak 
menyerupai pakaian laki-laki, (6) tidak menyerupai pakaian khas perempuan kafir, (7) tidak merupakan pakaian syuhrah, yaitu pakaian yang menarik perhatian dan dianggap aneh. ${ }^{6}$

\subsubsection{Prilaku Perempuan Terhadap Laki-laki}

Selain persyaratan kewajiban ber-hijab, WI juga mengatur bagaimana perempuan berprilaku terhadap lawan jenisnya. Dalam konteks ini, perempuan dilarang untuk: (1) berbicara dengan suara nyaring dan merendahkan suaranya ketika berhadapan dengan lawan jenisnya ataupun di depan publik, (2) sering ke luar rumah, (3) ber-tabarruj (berdandan dan berhias yang dianggap dapat menarik perhatian para laki-laki) ketika keluar rumah, (4) ber-khalwat (berduaduaan) dengan lelaki yang bukan mahramnya, (5) Memandang lawan jenis dengan syahwat, berpacaran, berkomunikasi bebas antara laki-laki dan perempuan. ${ }^{7}$

Dalam buletin mingguan Al-Balagh WI (edisi 40) dengan judul 'Bahaya Mengumbar Aurat' dijelaskan secara rinci mengenai perempuan yang sering keluar rumah lalu berdandan. Perempuan yang bersolek lalu keluar rumah adalah mudharatbesar terhadap masyarakat karena dianggap akan bisa memengaruhi perempuan-perempuan lainnya untuk melakukan hal yang serupa. Ini dikaitkan dengan beberapa ayat Al-Quran. Salah satu dari ayat AlQuran yang dikutip tersebut adalah: 'Dan hendaklah kamu tetap dirumahmu dan janganlah kamu berhias dan bertingkah laku seperti orang-orang jahiliyah yang terdahulu' (Q.S. Al-Ahzab:33).Ini tidak berarti bahwa perempuan dilarang keluar rumah, tapi ini mengindikasikan bahwa jika perempuan tidak dapat 'menahan diri untuk berhias dan mempertontonkannya', maka rumah menjadi tempat yang terbaik bagi perempuan.

\subsubsection{Menjadi Seorang Ibu}

WI memiliki norma yang spesifik tentang bagaimana 'menjadi seorang ibu', yang merupakan sebuah kemulian yang diberikan oleh Allah kepada seorang perempuan. Oleh karena itu, 'menjadi seorang ibu' adalah peran yang sangat penting bagi seorang Muslimah karena di pundaknya diberikan tugas 'menciptakan' anak yang berakhlak baik dan percaya kepada Allah.

\footnotetext{
${ }^{6}$ (http:/ / wahdahmakassar.org/syarat-dan-ketentuan-hijab-yang-sesuai-syariat-islam/)

7 (http://wahdahmakassar.org/wanita-cobaan-bagi-kaum-pria/)
} 
Tugas seorang istri atau seorang ibu juga dijelaskan dalam sebuah artikel pada website WI yang diberi judul Hak dan Kewajiban Istri, yang menyatakan bahwa kewajiban seorang istri adalah menjadi istri shalihah, mendidik anak-anaknya, menjaga rumah, dan tidak menyebarkan aib suaminya. Sedangkan hak dari seorang istri adalah mendapatkan nafkah, mendapatkan pergaulan yang baik, mendapatkan pendidikan dan pembinaan dari sang suami, dan tidak dapat dihukum kecuali dengan hukuman syar'i (Syariat Islam). Ke-shalih-an seorang istri ditandai dengan ketaatannya terhadap perintah Allah dan Rasul-Nya, serta kepada sang suaminya. Penjelasan ini menekankan pentingnya kedudukan suami dalam keluarga sebagai pembina istrinya untuk menjadi shalihah, dimana ketaatan seorang istri terhadap suaminya ditempatkan setelah ketaatan seorang istri terhadap Allah dan Rosulnya.

Dalam urusan pendidikan dan menjaga rumah dijelaskan pula oleh WI yang juga terdapat pada Website mereka, bahwa salah satu kewajiban yang terkadang dilalaikan oleh seorang ibu adalah pendidikan terhadap puteraputerinya. Meskipun pendidikan adalah kewajiban kedua orang tua, namun ibu yang lebih dominan berperan di dalamnya. Demikian halnya dengan menjaga rumah yang dalam konteks ini dikaitkan dengan mengatur urusan rumah tangga (seperti memasak, membersihkan rumah, dll.), dimana ibu berperan sentral.

Dalam artikel lain dijelaskan bahwa tidak ada salahnya jika seorang suami ikut membantu dalam urusan rumah tangga demi meringankan beban istrinya. Hal ini dikaitkan dengan sebuah Hadits yang menyatakan: dari Al Aswad beliau berkata: 'Saya bertanya kepada Aisyah, apakah yang dilakukan nabi di tengah keluarganya?' 'Aisyah menjawab: 'Beliau senantiasa membantu pekerjaan rumah isterinya, apabila tiba waktu shalat, maka beliau bangkit untuk melaksanakan shalat' (HR. Bukhari). ${ }^{8}$

Meskipun urusan rumah tangga lebih ditekankan sebagai 'urusan istri', bekerja di luar rumah bagi anggota WI tidak dilarang dengan sejumlah kondisi, yaitu: (1) tidak terjadi ikhtilat (bercampur baur) antara laki-laki dan perempuan' (2) bekerja atas persetujuan dari suami, ayah, saudara laki-laki atau orang yang bertanggung jawab terhadapnya, (3) bekerja di tempat yang sesuai dengan kapasitasnya, (4) bekerja di tempat yang bermanfaat bagi masyarakat, seperti menjadi tenaga pendidik, tenaga kesehatan dll., (5) bekerja yang tidak menyita

8 (http://wahdah.or.id/rasulullah-shallallahu-alaihi-wa-sallam-juga-biasa-membantupekerjaan-isteri-isterinya/) 
sebagian besar waktunya. Sehingga ia dapatmenyisihkan waktu untuk menunaikan kewajiban-kewajiban rumah tangga, melayani suami dan memperhatikan pendidikan anak-anak. ${ }^{9}$

Berbagai lapangan pekerjaan yang sesuai dengan batasan di atas dibuka oleh WI, seperti menjadi tenaga pendidik, tenaga kesehatan dll hal ini terbukti dengan sekolah yang dibangun oleh WI, dan apotik bagi anggotanya yang ingin bekerja dan pada saat yang sama tidak ingin meninggalkan tugas sebagai seorang ibu rumah tangga. Dalam kaitan dengan ini Rachman (2002:35), dalam artikelnya yang berjudul Penafsiran Islam Liberal atas Isu-isu Gender dan Feminisme di Indonesia, menyatakan bahwa jika agama itu menganut sistem patriarki yang dimana biasanya sistem ini mengasingkan perempuan di rumah, maka laki-laki lebih potensil menguasai kaum perempuan. Kadang-kadang sistem ini memperbolehkan perempuan aktif di dunia publik, tetapi dengan satu catatan, tidak melupakan kodrat [sosialnya], yakni: mengurus anak, suami, dan keluarga'.

Aspek lainnya yang terkait dengan 'menjadi seorang ibu' adalah pengaturan mengenai jumlah anak dan jarak kelahiran. Dalam perspektif WI yang di tuangkan kedalam fatwa, bahwa membatasi jumlah anak dilarang. Namun, mengatur jarak kehamilan diperbolehkan dengan alasan seorang perempuan tidak begitu kuat untuk melahirkan dalam jangka waktu yang yang berdekatan antara satu anak dengan anak berikutnya. ${ }^{10}$ Hal ini kontradiktif dengan kebijakan pemerintah sejak zaman Orde Baru, seperti yang dijelaskan Harlan (2014) tentang pembatasan jumlah anak dengan filosofi 'dua anak cukup' yang dijadikan sebagai dasar dalam membangun keluarga.

\subsection{Praktik Nilai-Nilai Ideal}

Penggambaran nilai-nilai ideal keperempuanan dalam praktiknya dijelaskan berdasarkan kategori keanggotaan WI, yaitu anggota baru, guru (murabbiah), dan pengurus Lembaga Muslimah WI.

\subsubsection{Anggota Baru}

Anggota baru adalah anggota yang belum menikah dan masih dalam tahap beradaptasi dengan nilai ideal yang ada dalam organisasi WI, seperti dalam pemakaian hijab yang ideal yang sesuai dengan syariat, dan bagaimana

\footnotetext{
9 (http://wahdah.or.id/wanita-bekerja/)

10 (http://wahdah.or.id/mengatur-jarak-kelahiran/).
} 
seharusnya seorang perempuan berkelakuan terhadap laki-laki, terutama yang bukan mahram-nya.

Dalam praktiknya cara berhijab anggota baru sebenarnya telah memenuhi syarat dari pakaian syar'i, tetapi diantara anggota WI terdapat model pakaian standar yang dianggap sebagai model pakaian syar'i (yang akan didiskusikan kemudian), sehingga memunculkan istilah 'level-level dalam ber-hijab'. Perkembangan penggunaan hijab dari satu level ke level selanjutnya disebut dengan istilah 'hijrah pakaian', yang jika dilihat terdapat 4 level. Namun apapun levelnya, pakaian yang digunakan tidak memperlihatkan bentuk tubuh (longgar).

Hijab yang digunakan anggota baru berada pada level 1 dan 2 dalam hijrah pakaian. Pada level 1 pakaian yang digunakan rok panjang dengan blus lengan panjang dan kaos kaki. Pada level ini jilbab (penutup kepala) digunakan sangat bervariasi, mulai daripenggunaan jilbab 1 lapis dengan bahan yang tebal; 2 lapis dengan bahan tipis untuk mencegah penampakan rambut; dan 2 lapis dengan bahan tebal (lihat Gambar 2).

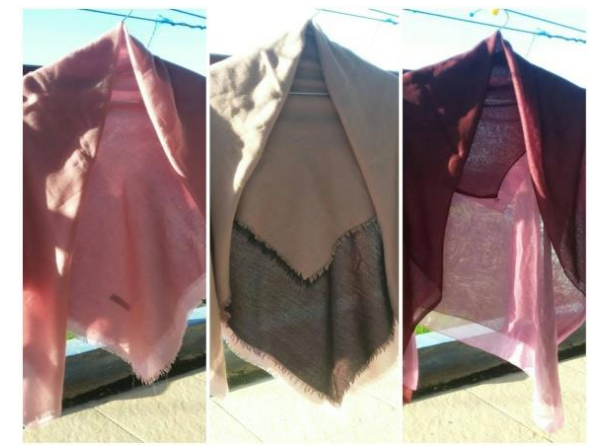

Gambar 2. Ragam jilbab anggota baru (Level 1)

Pada level 2, pakaian yang digunakan adalah gamis terusan yang biasanya disertai dengan memakai rok di dalam gamis tersebut. Ini dimaksudkan agar pakaian tidak tembus pandang yang disertai dengan memakai kaos kaki. Jilbab yang digunakan berbahan yang tebal, sehingga dengan mengenakan satu lapis saja sudah tidak transparan dan ukuran jilbabnya lebih besar dari level sebelumnya (lihat Gambar 3) 


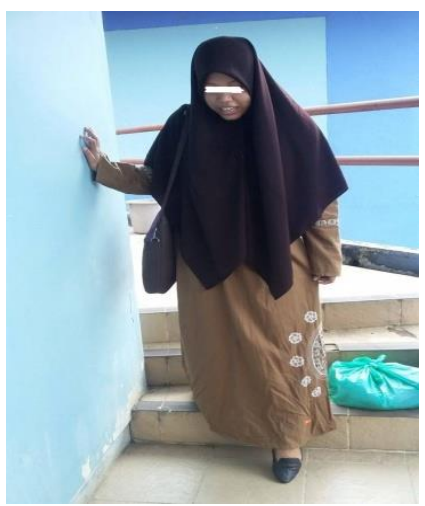

Gambar 3. Hijab Level 2

Cara ber-hijab anggota baru berada diantara level 1 dan 2. Anggota baru, seperti Ifah (19 tahun) mengatakan bahwa cara ia mengenakan hijab sekarang hanya merupakan langkah awal karena ia masih membutuhkan bimbingan dari kakak-kakak/guru-guru (murabbiah). Dia berharap dengan bertambahnya ilmu agama (Islamnya), ini akan berdampak pula terhadap caranya berpakaian.

Jika Ifah menginginkan perubahan secara bertahap dalam berpakaian, maka anggota baru yang lain-Mawar (20 tahun)-memiliki alasan yang berbeda kenapa ia belum sepenuhnya memenuhi cara ber-hijab yang diidealkan oleh WI. Dia sebenarnya menginginkan untuk berpakaian lebih syar'i, tetapi dia belum mendapatkan persetujuan dari orang tuanya karena dianggap model pakaian tersebut terlalu ekstrim. Selain itu, orang tuanya takut jika ia di curigai sebagai bagian dari teroris (baca, misalnya, Nisa 2012).

Meskipun berdandan lalu keluar rumah merupakan hal yang dilarang bagi perempuan, tetapi banyak dari anggota baru yangmasih melakukannya. Ifah (19 tahun), misalnya, masih menggunakan lipstik dengan warna-warna natural yang sesuai dengan warna bibir agar tidak menarik perhatian lawan jenisnya (seperti coklat muda, peach, dll.). Dalam konteks ini, peenggunaan lipstik dengan warna-warna natural adalah cara anggota baru dalam menegosiasikan antara norma yang ideal dan yang dipraktikkan.

Dalam hal berprilaku terhadap laki-laki, seperti dijelaskan di artikel yang diposting oleh WI dengan judul 'Resep Jitu Menjaga Kehormatan Muslimah', salah satu resep yang disampaikan adalah 'menjaga jarak dengan kerabat dekat yang bukan mahram', termasuk ipar. Hal ini menunjukkan jika perempuan dan laki-laki tidak dibebaskan untuk saling berinteraksi kecuali dalam hal-hal tertentu. Dwi (23 tahun), yang seorang murabbiah, memberikan contoh yang memperbolehkan perempuan berinteraksi dengan laki-laki adalah saat 
menuntut ilmu, interaksi seorang dosen laki-laki dengan murid perempuannya, seorang ustadz dengan muridnya. Selain itu, ada pula 'resep' yang menjelaskan bagaimana perempuan seharusnya bersikap terhadap laki-laki, seperti menundukkan 'pandangan', menjaga kemaluan, ketegasan ketika berbicara kepada lelaki non-mahram, menghindari suara yang mendayu-dayu, dan menjauhi berpacaran dalam berbagai bentuknya. ${ }^{11}$

Bagi Mawar, yang masih berstatus anggota baru, cara berperilaku terhadap laki-laki masih merupakan sebuah dilema, karena ia adalah tipe orang yang cerewet dan sangat susah baginya untuk mengurangi atau bahkan tidak berinteraksi dengan laki-laki. Terlebih lagi teman laki-lakinya masih memperlakukannya seperti dahulu sebelum ia memutuskan untuk menjadi anggota WI. Tetapi ia tetap mencoba untuk mengurangi interaksinya terhadap laki-laki, baik melalui bertatap muka secara langsung, maupun melalui media sosial.

\subsubsection{Guru (Murabbiah)}

Tingkatan keanggotaan setelah anggota baru adalah murabbiah. Menjadi seorang murabbiah juga merupakan 'tanda' jika seorang anggota telah berada di level selanjutnya karena sejumlah indikator, misalnya dalam cara mereka berpakaian (ber-hijab), cara mereka berinteraksi dengan lawan jenis, pemahaman mengenai ajaran Islam, dll.

Setiap anggota WI yang berstatus murabbiah memiliki satu kelompok tarbiyah (pendidikan), yakni kelompok diskusi mengenai Islam, misalnya sejarah perjuangan Rasullullah, perbaikan tajwid bacaan al-Quran, bagaimana seharusnya seorang Muslimah (misalnya, perempuan yang menjaga pandangannya, menutup aurat, dll.).

Dalam memraktekkan nilai-nilai ideal keperempuanan, murabbiah secara relatif setingkat lebih tinggi dalam mengaplikasikan nilai-nilai ideal tentang keperempuanan dalam kehidupan sehari-hari dibandingkan dengan anggota baru. Sida (21 tahun), misalnya, merupakan seseorang murabbiah yang sangat senang berdandan. Namun, ia hanya memakai riasan ketika ia berada di rumah. Meskipun perempuan ingin terlihat cantik oleh orang lain, namun ia percaya bahwa norma yang diatur dalam Islam adalah demi kebaikan Muslimah itu sendiri.

${ }^{11}$ (http:// wahdahmakassar.org/resep-jitu-menjaga-kehormatan-muslimah/) 
Bagi Siska (24 tahun), seorang Muslim/Muslimah ketika merespon suatu perintah baik dari Al-Quran maupun Sunnah Rosul hanya ada satu jawaban, yaitu 'kami dengar dan kami taati' (sami'na wa ata'na). Menurutnya, keyakinan seperti itulah yang harus selalu dipegang oleh setiap Muslim, bukan keyakinan dimana 'kami mendengar, lalu kami mempertentangkannya dengan akal'.

Pada level murabbiah, bercadar adalah tingkatan tertinggi dalam berpakaian dan merupakan sebuah tingkatan yang sangat ingin dicapai oleh seorang murabbiah, dimana mereka telah memakai hijab besar. Pada tingkatan ini, bercadar tidak sekedar menutup seluruh tubuh, tetapi juga menutup sebagian dari wajah mereka. Jika diobservasi, maka level cara ber-hijab seorang murabbiah berada pada 2 level teratas, yaitu level 3 dan 4, yang menurut anggota WI, merupakan level dengan jenis pakaian syar'i, seperti yang telah dijelaskan sebelumnya (lihat sub-sessi anggota baru di atas) anggota WI memiliki model pakaian yang dianggap jika model pakaian tersebutlah yang merupakan pakaian syar'i dan model pakaian syar'i inilah yang dikenakan oleh murabbiah.

Model ber-hijab murabbiah pada level 3 mirip dengan mukena yang biasa digunakan untuk sholat oleh seorang Muslimah, yaitu jilbab besar menutupi kedua lengan dan tangan. Jika seseorang menggunakannya, maka di dalam jilbab mereka yang besar, ia juga mengenakan satu lapis jilbab yang ukurannya lebih kecil dibanding jilbab luar. Sedangkan model baju yang digunakan bermacam-macam, mulai dari yang mengenakan blus panjang dengan rok sampai yang menggunakan gamis panjang. Yang membedakan model hija blevel 3 dan level 4 hanya pada penggunaan cadar yang menutupi sebagian wajah (lihat Gambar 4).

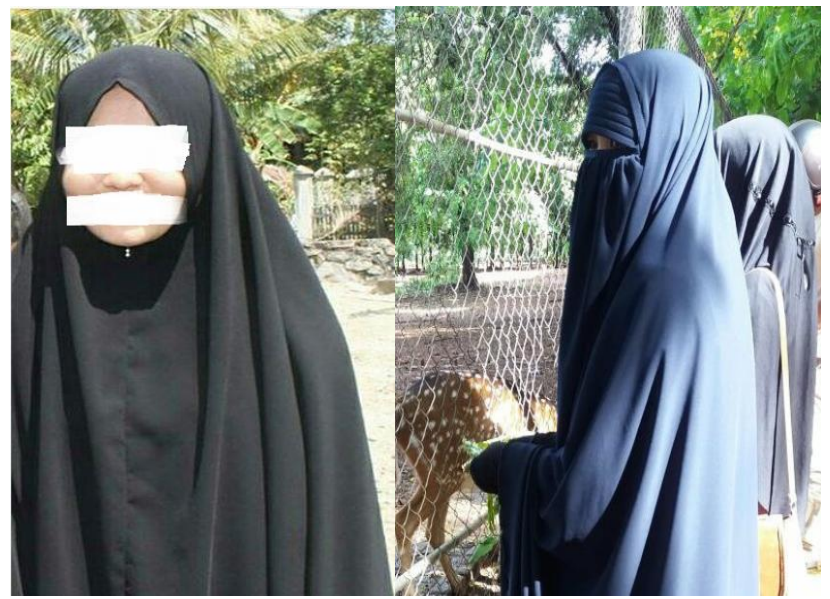

Gambar 4. Pakaian Syar'i level 3 dan 4 (dari kiri ke kanan) 
Masalah yang muncul dalam kaitan dengan bercadar adalah ketidak-setujuan orang tua jika anaknya menggunakan model pakaian seperti itu. Namun Rina (24 tahun) memiliki strategi tersendiri untuk mengatasi masalah tersebut. Dia mengganti cadar dengan masker, sehingga orang tuanya menganggap, bahwa masker berfungsi untuk melindungi dirinya dari debu karena sehari-harinya Rina menggunakan motor sebagai alat transportasi (lihat Gambar 5 dibawah). Strategi ini tidak saja mengindarkan dirinya dari konflik dengan orang tuanya, tapi juga dia tetap dapat memenuhi keinginannya untuk menggunakan cadar karena baginya masker juga bisa menutup wajahnya selayaknya jika ia menggunakan cadar. Selain itu, ia tetap memberikan pemahaman kepada orang tuanya tentang pentingnya penggunaan cadar.

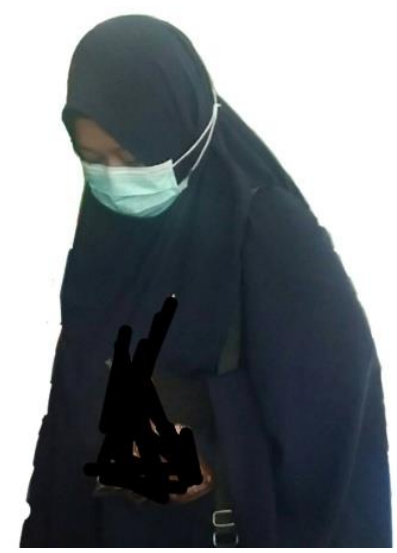

Gambar 5. Perempuan bermasker

Namun, ada perdebatan diantara anggota WI tentang bercadar. Perdebatan yang muncul terkait dengan apakah bercadar itu sebuah kewajiban, sunnah atau hanya sebatas keutamaan bagi seorang Muslimah. Setiap anggapan ini memunculkan pendapat mengenai dimana seharusnya seorang Muslimah bisa membuka cadarnya, anggota yang menganggap bahwa cadar adalah sebuah kewajiban tidak akan membuka cadarnya di hadapan laki-laki yang bukan muhrimnya, sekalipun laki-laki tersebut adalah keluarga dekat, seperti iparnya. Anggota yang memahami bercadar adalah sunnah beranggapan jika mereka dapat membuka cadarnya dihadapan keluarga dekatnya. Sedangkan, bagi anggota yang menganggap cadar sebagai sebuah keutamaan bagi seorang Muslimah membuka cadarnya dihadapan seorang laki-laki yang dia kenal walaupun bukan keluarga dekat.

Dalam hal berinteraksi dengan lawan jenis, murabbiah tidak melakukannya secara langsung. Nisa (23 tahun), misalnya, mengatakan bahwa jangankan 
berbicara dengan laki-laki, melihat ada pasangan yang sedang asyik berpacaran saja ia langsung menutup matanya. Dalam konteks ini, melihat orang lain berduaan saja ia hindari, apa lagi melakukannya sendiri. Dengan cara demikian, ia menjaga 'pandangannya' dari hal-hal yang tidak pantas dilakukan.

Interaksi antara perempuan dan laki-laki juga dapat diobservasi ketika LDKMPM (Lembaga Dakwah Kampus Mahasiswa Pecinta Musholah) melakukan musyawarah, dimana ruang antara laki-laki dan perempuan dibatasi oleh hijab (tirai). Rosna (25 tahun) mengatakan bahwa ia berinteraksi dengan laki-laki hanya ketika LDK-MPM mengadakan forum musyawarah. Topik yang umumnya didiskusikan antara perempuan dan laki-laki juga sebatas masalah terkait organisasi dan bagaimana penyelesaian masalah. Namun, interaksi yang terjadi bukan berupa interaksi tatap muka secara langsung (face to face), tapi berkomunikasi melalui surat ataupun berkomunikasi dengan dibatasi oleh tirai (hijab).

Hal ini merupakan 'cara' bagi mereka untuk membatasi interaksi langsung antara perempuan dan laki-laki, yang diekspresikan dalam sebuah frasa: 'menjaga hijab-nya' yang bermakna 'menjaga pandangan'. Sinta (23 tahun) mengatakan ketika ia berkomunikasi dengan laki-laki, dia hanya 'mengenal suara' dari lawan jenisnya tanpa mengenal wajahnya. Bagi mereka wajah tidak penting, yang signifikan untuk diketahui adalah 'pesan yang disampaikan'.

Wessler berpendapat hijab merefleksikan stereotip pria Muslim yang menekan Muslimah (Wessler dalam Nizmi 2015:1624). Namun, anggota WI menganggap bahwa norma-norma yang terkait dengan keperempuanan yang diatur dalam organisasi WI bukan sebuah bentuk penindasan, justru aturan tersebutlah yang seharusnya diberlakukan bagi perempuan karena dengan cara seperti itu mereka 'saling menjaga' dan 'saling menghargai' antara perempuan dan lakilaki.

Murabbiah juga membatasi interaksinya dengan laki-laki melalui media sosial. Rina (24 tahun) hanya menerima permintaan pertemanan yang dikirim oleh teman perempuan, ia juga mengatur akun media sosialnya dalam mode pribadi (private). Ini tidak berarti, bahwa ia membuat kehidupan dunia mayanya menjadi sangat tertutup dari laki-laki. Berteman dengan laki-laki di facebook masih dilakukannya dengan pengecualian, yakni menerima pertemanan 
dengan ustadz-ustadz yang selalu memosting mengenai ajaran Islam di akunnya.

Murabbiah memiliki kriteria calon suami idaman seperti kebanyakan perempuan lainnya. Siska (24 tahun), misalnya, menyatakan jika ia ingin menikah dengan laki-laki yang juga 'menjaga pandangannya' dari lawan jenis dan memiliki iman yang kuat, sehingga bisa menuntunnya menjadi perempuan shaliha.

Murabbiah juga memiliki konsep pernikahan yang diinginkan, yaitu walimah syar'i, yakni konsep perkawinan yang memisahkan ruangan antara tamu lakilaki dan tamu perempuan agar tidak terjadi pencampurbauran antar keduanya (lihat Gambar 6 di bawah). Namun, pada banyak kasus orang tua dari anggota WI yang tidak setuju dengan konsep tersebut, sebagaimana yang dialami Siska (24 tahun). Meskipun orang tua Siska menolak konsep perkawinan walimah syar'i, dia tetap berupaya untuk meyakinkan orang tuanya agar mau mengikutinya. Namun, hingga saat ini orang tua dari Siska masih belum menyetujui konsep perkawinan seperti itu.

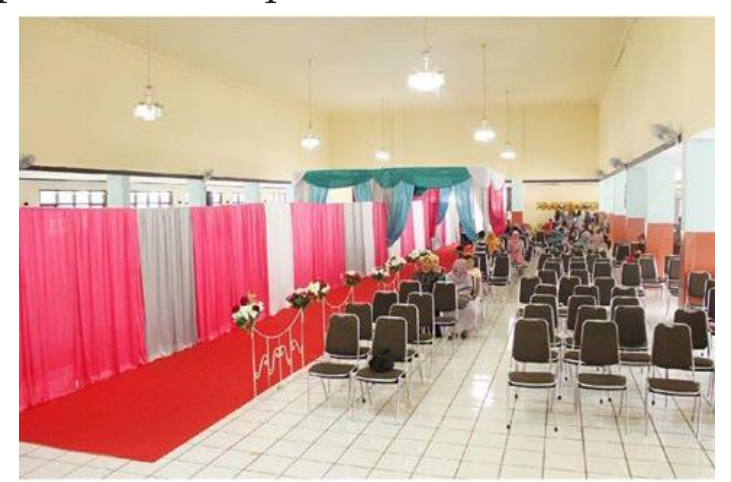

Gambar 6. Konsep Walimah Syar'i

Namun, pertentangan antara murabbiah dengan orang tua tidak hanya terkait dengan cara berpakaian dan konsep perkawinan, tapi juga berhubungan dengan kriteria calon pasangan yang dinginkan. Seorang murabbiah menginginkan seorang pasangan yang tidak saja 'menjaga pandangannya' yang juga melaluinya ia 'menjaga kemaluannya', tapi juga yang memiliki iman berdasarkan prilakunya sehari-hari sebagai seorang Muslim. Umumnya penampilan fisik dari kriteria 'pasangan ideal' bagi seorang murabbiah yang dapat diobservasi adalah seorang laki-laki yang berjenggot dan mengenakan celana atau gamis yang panjangnya hanya sampai diatas mata kaki. Akan tetapi, laki-laki dengan penampilan seperti ini ditentang oleh orang tua murabbiah karena, seperti halnya dengan penggunaan cadar, penampilan 
seperti ini dianggap terlalu ekstrim dan seperti penampilan pelaku teror. Rosna (25 tahun) mengatakan jika ia terpaksa menolak lamaran seorang laki-laki yang sesuai dengan kriterianya itu karena kedua orang tuanya, bahkan seluruh keluarganya tidak menyetujuinya. Pada kasus dimana orang tua tidak menyetujui pernikahan dengan konsep walimah syar'i maupun pasangan dengan kriteria seperti yang disebutkan di atas, maka murabbiah akan menolak lamaran orang tersebut karena menganggap restu ortu lebih diperlukan.

\subsubsection{Pengurus Lembaga Muslimah}

Kategori anggota yang ketiga adalah pengurus Lembaga Muslimah (Lajna AlMuslima) WI yang anggotanya hampir semuanya berstatus menikah (istri/ibu). Menurut ketua Lembaga Muslimah WI, peran menjadi seorang ibu adalah segalanya dan merupakan sebuah kehormatan bagi perempuan, yang menurut Badawi (2008:12) merupakan tugas yang suci, mulia dan vital. Ini karena ada nilai yang ditanamkan kepada anggota WI, bahwa seorang anak akan menjadi 'jembatan' bagi ibunya menuju surga. Oleh karena itu, mereka tidak membatasi seberapa banyak anak yang diinginkan, semua tergantung dari Allah, tinggal mengatur jarak kelahiran antar anak karena mereka menyandarkan diri pada pemahaman bahwa jika banyak anak, maka banyak 'jembatan' menuju sorga, sebagai sebuah 'investasi masa depan' yang bersifat kekal.

Memiliki anak identik dengan menjadi seorang ibu. Dalam kaitan dengan ini, Sakinah (40 tahun), Humas Lembaga Muslimah WI, menyatakan bahwa jika nanti ia meninggal, masih ada anaknya yang akan mendoakannya (Syam dan Idrus 2017, edisi ini). Ini menunjukkan pentingnya menjadi seorang ibu dan memiliki anak yang soleh dan shaliha karena anak-anak yang demikian yang akan mendoakan ibunya. Banyak anak banyak yang mendoakan dan ini berkelindan dengan norma yang tidak membolehkan pembatasan jumlah anak sebagaimana dijelaskan di atas.

Hal ini juga menjadi alasan mengapa jika seorang anggota ingin menjadi wanita karir, anak selalu menjadi pertimbangan utama. Dalam banyak kasus, mereka akan melamar pekerjaan atau menerima pekerjaan yang ditawarkan jika dia bisa membawa anaknya ke tempat kerja, sehingga anak-anak tetap berada di bawah pengawasan ibunya saat bekerja (lihat Gambar 7). 


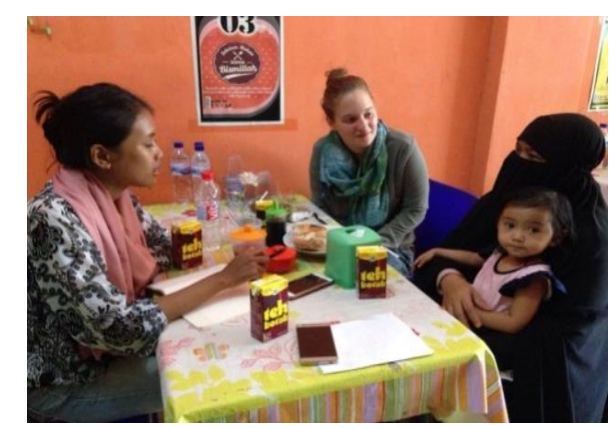

Gambar 7. Ibu dan anak di tempat kerja

Jikapun anak harus dititipkan, maka orang yang dititipi adalah orang tua selama jam kerja. Tetapi jika seorang ibu tidak dapat mengatur waktu antara bekerja dengan tanggung jawab domestiknya, maka dia lebih memilih untuk berhenti bekerja. Hilda (40 tahun), yang seorang dosen, mengatakan bahwa sebagai seorang ibu ia harus menyeimbangkan antara pekerjaan dengan tanggung jawab rumah tangga. Namun, sesibuk apapun Sakinah (40 tahun), dia menganggap bahwa anak-anak harus dibesarkannya sendiri, ia tidak dapat mengenyampingkan perannya sebagai ibu dengan alasan bekerja. Ini diperkuat oleh pendapat Melati (41 tahun) yang mengungkapkan, bahwa ibu memainkan peran yang sangat penting dalam kaitan dengan masa depan anak-anaknya, kesuksesan seorang anak bergantung pada seorang ibu karena seorang ibu merupakan 'agen pendidik pertama dan utama' bagi anak-anaknya, sebagaimana peran ideal perempuan dalam Islam (Abdullah 2001:25). Ini menunjukkan bagaimana perempuan meletakkan peran penting ibu dalam kaitan dengan pengasuhan dan pendidikan anak.

Dalam kaitan dengan pengasuhan anak, Darajat (1992:71) menjelaskan bahwa jika seorang ibu sabar, penuh kasih sayang, bijaksana dan pendidik yang baik, ini tidak hanya akan menghasilkan 'anak-anak yang bahagia', tetapi juga akan membentuk 'keluarga yang bahagia'. Sebaliknya, jika seorang ibu merupakan seorang yang pemarah, gelisah, sedih maka keluarganya juga akan seperti itu. Tasnim (2012) menganggap bahwa pandangan Islam mengenai ibu yang merupakan pandangan yang tradisional dimana seorang ibu yang buruk akan menghasilkan anak yang buruk pula, apapun yang terjadi dengan anak pasti berhubungan dengan ibu. Artinya, baik-buruknya seorang anak tergantung pada ibunya, dan mengabaikan peranan ayah dalam proses pengasuhan karena pengasuhan dikonstruksikan sebagai tugas ibu.

Sementara pengurus Lembaga Muslimah WI, yang bukan merupakan seorang ibu ataupun seorang istri, dan telah berada pada usia yang dianggap sudah 
pantas untuk menikah bagi seorang perempuan, maka dalam kesehariannya mereka berfokus kepada bagaimana mempersiapkan diri mereka untuk menjadi seorang ibu atau istri. Salah satu program yang merupakan aktivitas rutin dari WI adalah program yang terkait dengan bagaimana mempersiapkan calon ibu atau istri bagi anggota-anggotanya, seperti bagaimana membangun rumah tangga, cara mendidik anak dan bagaimana menghasilkan anak yang sholeh, dll. Hani (28 tahun) sering mengikuti pertemuan-pertemuan terkait sebagai bekal ia nanti ketika telah menikah.

\section{Kesimpulan}

Wahdah Islamiyah, sebuah organisasi yang bernaung di bawah Yayasan Pesantren Wahdah Islamiyah (YPWI), adalah pengikut ajaran salafi yang merupakan gerakan yang mencoba mempraktikkan nilai-nilai Islam yang dipraktikkan oleh Al-Salaf As-Sālih, yakni tiga generasi pertama Islam yaitu Nabi dan sahabatnya, tābi'een (pengikut dari nabi dan sahabatnya), dan tābi'u altābi'een (pengikut dari tābi'een).

Nilai keperempuanan yang ideal bagi WI menyangkut bagaimana perempuan seharusnya berpakaian, berperilaku terhadap lawan jenis, dan 'menjadi seorang ibu' yang kemudian di aplikasikan kedalam kehidupan sehari-hari anggota perempuan WI. Nilai-nilai ini sebelumnya disebarkan melalui berbagai media, seperti buku, selebaran, artikel, fatwa dan melalui aktivitas internal dari organisasi WI itu sendiri untuk diadopsi secara internal oleh anggotaanggotanya.

Dalam organisasi WI, anggota terklasifikasi ke dalam 3 kategori, yakni anggota baru, guru (murabbiah), dan pengurus Lembaga Muslimah WI. Anggota WI mentransformasikan diri secara spiritual berdasarkan nilai-nilai keperempuanan yang dinormakan dalam organisasi berdasarkan kategori keanggotaannya di WI. Dalam praktiknya, nilai-nilai keperempuanan yang ideal tersebut tidak selalu sinkron dengan apa yang praktikkan oleh anggota tergantung pada bagaimana mereka mempersepsikan nilai-nilai tersebut dan 'nilai apa dan kondisi apa' yang dihadapi oleh anggotanya.

Anggota baru cenderung memiliki 'ruang' untuk negosiasi karena mereka masih dalam proses belajar memraktekkan nilai-nilai tersebut; murabbiah setingkat lebih advance dalam mengaplikasikan nilai-nilai ideal WI itu dalam kehidupan sehari-hari, yang dapat dilihat dari cara berpakaian (ber-hijab), dan cara mereka berinteraksi dengan lawan jenis. Berbeda dengan kedua klasifikasi 
diatas, anggota yang merupakan pengurus Lembaga Muslimah WI lebih berfokus kepada bagaimana memraktekkan nilai-nilai ideal tersebut dalam kaitan dengan bagaimana 'menjadi seorang ibu/istri'. Dengan demikian, perempuan bertransformasikan diri secara spiritual berdasakan nilai-nilai keperempuanan yang berkelindan dengan keanggotaan dan level mereka di organisasi WI.

\section{Daftar Pustaka}

\section{Buku dan Jurnal}

Abdullah, Adil Fathi. (2001). Menjadi Ibu Ideal. Jakarta: Pustaka Al-Kautsar.

Al-Balagh. (2016). Bahaya Mengumbar Aurat (edisi 40) Makassar: Wahdah Islamiyah Makassar.

Berkovitch, Nitza. (1997). Motherhood as a National Mission: The construction of Womanhood in the Legal Discourse in Israel, sciencedirect.com, diakses tanggal 20 Maret 2017.

Blackburn, Susan. (2008). 'Indonesian Women and Political Islam,' Journal of Southeast Asian Studies, Februari, 39(1):83-105.

Darajat, Zakiah. (1992). Kesehatan Mental dalam Keluarga. Jakarta: Pustaka Antara.

Deed, Lara. (2006). An Enchanted Modern: Gender and Public Piety in Shi'i Lebanon. Princeton: Princeton University Press.

Deller, Ruth A. (2015). 'Religion as Makeover: Reality, Lifestyle and Spiritual Transformation', http:/ /journals.sagepub.com/doi/pdf/10.1177/1367877913513687, diakses tanggal 23 Desember 2016.

Engineer, Asghar Ali. (1992). The Rights of Women in Islam. Delhi: Sterling Publishers.

Harlan, Sarah V. (2014). 'Two is Enough': Rights-Based Family Planning in Indonesia. k4health.org, diakses tanggal 25 Oktober 2016.

Jahan, Ishrat (2015). 'The Social Construction of 'Self' and Womanhood in a Hindu Village of Bangladech', Journal of World Anthropology, 3(1):42-51.

Mernissi, Fatema. (1991). Women and Islam: An Historical and Theological Enquiry. Oxford: Basil Blackwell.

Nisa, Eva F. (2012). Cadari of Wahdah Islamiyah: Women as Dedicated Actors of Ultraconservatism. http://intersections.anu.edu.au/issue30/nisa.html, diakses tanggal 25 Oktober 2016. 
Nizmi, Yusnarida Eka. (2015). 'Pandangan Amerika Terhadap Perempuan Muslim PascaSeranganSebelas September 2001', Jurnal Kajian Politik dan Masalah Pembangunan, 11(1):1623-1632.

Qibtiyah, Alimatul. (2012). 'The Conceptualisation of Gender Issues among Gender Activists and Scholars in Indonesian Universities', http://intersections.anu.edu.au/issue30/qibtiyah.htm\#n3, diakses tanggal 15 April 2017.

Rachman, Budhy M. (2002). ‘Penafsiran Islam Liberal Atas Isu-isu Gender dan Feminisme di Indonesia', dalam S.R. Dzulhayatin, B. Munawar-Rachman, N. Umar (eds.), Rekonstruksi Metodologis Wacana Kesetaraan Gender dalam Islam. Yogyakarta: Pustaka Pelajar, 27-81.

Rinaldo, Rachel. (2008). 'Envisioning the Nation: Women Activists, Religion and the Public Sphere in Indonesia,' Social Force, Juni, 86(4):1781-1804.

Robinson, Kathryn. (2006). 'Islamic Influences on Indonesian Feminism,' Social Analysis, 50(1): 171-77.

(2008). 'Islamic Cosmopolitics, Human Rights and AntiViolence Strategies,' Anthropology and the New Cosmopolitanism P. Werbner (ed.), Oxford, New York: Berg, 111-134.

(2009). Gender, Islam and Democracy in Indonesia. London and New York: Routledge.

Siddiqui, Samana. (2010). What's Wrong with MuslimSsocieties: A Critical Look at How We Treat Women. soundvision.com, diakses tanggal 20 Maret 2017.

Sugiyarto, Wahid. (2013). 'Al Wahdah Al-Islamiyah: Radikalisme dan Komitmen Kebangsaan', Harmoni: Jurnal Multikultural \& Multireligius, 12(1):86-99.

Syam, Mirawati dan Idrus, Nurul Ilmi. (2017). 'Butta Kodi, Biné Kodi': Gender, Stigma dan Dampaknya Terhadap Tu Tamanang di Kabupaten Gowa, Etnosia, 2(2):25-49.

Zine, Jasmine. (2002). 'Muslim Women and the Politics of Representation,' American Journal of Islamic Social Sciences, 19(4): 1-22.

Tasnim, Nur. (2012). Motherhood and Islam: The Reverred, the Bad, and the Mystical. Patheos.com, diakses 25 Oktober 2016.

Umar, Nasaruddin. (1999). Argumen Kesetaraan Gender: Perspektif Al-Qur'an. Jakarta: Paramadina. 
Wieringa, Saskia E. (2009). 'Women Resisting Creeping Islamic Fundamentalism in Indonesia,' Asian Journal of Women's Studies, http://www.aletta.nu/epublications/iav_b00103571.pdf, accessed 9 December 2011.

Wadud, Amina. (1993). Women in the Qur'an: Rereading a Sacred Text From a Woman's Perspective. Oxford: Oxford University Press.

\section{Internet}

Badawi, Jamal, A. (2008). Kedudukan Wanita Dalam Islam. http://raudhatulmuhibbin.blogspot.com, diakses tanggal 27 November 2016.

Stacey, Aisha. (2013). Does Islam Oppress Woman? islamreligion.com, diakses tanggal 20 Maret 2017.

https://hizbut-tahrir.or.id/2013/08/30/barat-justru-merendahkan-wanita/ 20 Mei 2017.

https://id.wikipedia.org/wiki/Wahdah_Islamiyah diakses tanggal 23 Mei 2017.

http:/ / wahdahmakassar.org/gerakan-penentang-hijab-dan-kiatmembendungnya/diakses tanggal 23 Oktober 2016.

http://wahdahmakassar.org/hak-dan-kewajiban-istri/ diakses tanggal 23 Oktober 2016.

http://wahdahmakassar.org/hijab-wanita-muslimah-1/ diakses tanggal 23 Oktober 2016.

http://wahdahmakassar.org/syarat-dan-ketentuan-hijab-yang-sesuai-syariat-is lam/ diakses tanggal 23 Oktober 2016.

http://wahdahmakassar.org/resep-jitu-menjaga-kehormatan-muslimah/ diakses tanggal 23 Oktober 2016.

http://wahdahmakassar.org/wanita-cobaan-bagi-kaum-pria/ diakses tanggal 23 Oktober 2016.

http://wahdah.or.id/mengatur-jarak-kelahiran/ diakses tanggal 23 Oktober 2016.

http://wahdah.or.id/rasulullah-shallallahu-alaihi-wa-sallam-juga-biasamembantu-pekerjaan-isteri-isterinya/ diakses tanggal 23 Oktober 2016.

http://wahdah.or.id/wanita-bekerja/ diakses tanggal 23 Oktober 2016.

http://www.wahdahtamalate.com/p/sejarah-singkat-berdirinya-wahdah.html diakses tanggal 23 Januari 2017. 